\title{
Problem Based Learning On Literacy Mathematics: Experimental Study in Elementary School
}

\author{
M. Farhan ${ }^{1}$, Rarasaning Satianingsih ${ }^{2}$, Via Yustitia ${ }^{3 *}$ \\ 1,2,3 Universitas PGRI Adi Buana Surabaya \\ *via.yustitia@unipasby.ac.id
}

Received: November 2020; Accepted: December 2020; Published: January 2021

\begin{abstract}
This research is motivated by the hope of students mastering mathematical literacy skills. Mathematical literacy can facilitate a person in understanding the usefulness of mathematics and applying it in everyday life to make the right decision. But in reality, based on the results of PISA 2018, Indonesia was decreased as a result of The Mathematical Literacy Ability Test. This study aims to determine: (1) The average literacy ability of experimental class students taught through PBL is better than the control class; (2) Class 5 student activities taught using the Problem Based Learning model, (3) Teachers can carry out learning using the Problem Based Learning learning model. This research is quantitative research with observation and documentation methods. The design used is a quasi-experimental design type Post-test only. This research uses an interval scale. The population is grade 5 students of SDN Gayungan II Surabaya. Samples were taken by cluster random sampling technique so that class 5-B (control class) and 5-A (experimental class) were obtained. Data collection techniques used were test methods analyzed with SPSS 22; observation of activities and implementation with descriptive; and documentation. The results showed that: (1) The average literacy ability of the experimental class students taught through PBL was better than the control class; (2) Student activities get very active categories; (3) The implementation of learning using the PBL model gets the good category.
\end{abstract}

Keywords: problem based learning, mathematics literacy ability.

How to Cite: Farhan, M., Satianingsih, R., \& Yustitia, V. (2021). Problem Based Learning On Literacy Mathematics: Experimental Study in Elementary School. Journal of Medives: Journal of Mathematics Education IKIP Veteran Semarang, 5(1), 118-128. 


\section{PENDAHULUAN}

Saat ini pemerintah sedang berupaya untuk mereformasi bidang pendidikan pada jaman revolusi industri 4.0. Reformasi tersebut menunjukan adanya potensi yang dapat membawa Indonesia menuju sudut pandang perubahan baru untuk mencapai tujuan yang telah ditetapkan. Salah satu sudut pandang tersebut adalah pendidikan yang tidak harus mampu menyiapkan siswanya memiliki keterampilan yang kompeten di dunia kerja, melainkan juga harus membentuk daya intelektual yang unggul dan juga berkarakter yang baik (Ibda \& Rahmadi, 2018, Fanny, 2019).

Sejalan dengan kondisi di atas, pemerintah merespon tantangan di era revolusi industri 4.0 dengan caragerakan literasi baru sebagai penguat gerakan literasi lama. Gerakan literasi baru yang dimaksudkan adalah tiga literasi utama yaitu: 1) literasi digital, 2) literasi teknologi, dan 3) literasi manusia (Ghufron, 2018). Berdasarkan penjelasan di atas, maka langkah yang tepat yang harus dilakukan guru adalah dengan mempelajari dan memahami makna sebenarnya dari kegiatan Gerakan Literasi Sekolah (GLS). GLS merupakan salah satu kegiatan usaha partisipatif dari pemerintah yang melibatkan seluruh warga sekolah (siswa, guru, kepala sekolah, wali murid), akademisi, penerbit, media massa, masyarakat (KemendikBud, 2016). Dengan kegiatan ini, diharapkan akan ada perkembangan kemampuan literasi dari siswa. Kemampuan literasi sendiri terbagi menjadi 4 jenis, yaitu: Literasi Membaca, Literasi Menulis, Literasi Matematika, dan Literasi Sains. Namun pada penelitian ini, peneliti berfokus pada Literasi Matematika sebagai subjek penelitian dikarenakan peneliti perihatin terhadap hasil nilai tes yang diadakan oleh Programme for International Student Assesment (PISA) yang diumumkan Kemendikbud pada tahun 2018.

Pada tahun 2018, Kementerian Pendidikan dan Kebudayaan telah merilis hasil pencapaian nilai PISA yang dilakukan tes survey pada tahun 2018. Skor program PISA tersebut menempatkan Indonesia menghuni peringkat ke-72 dari 78 negara yang menjadi peserta tes tesebut dengan skor 397 dan rata-rata OECD sebesar 489. Berdasar nilai rerata, terjadi penurunan nilai PISA Indonesia di kompetensi yang diujikan. Penurunan juga terlihat pada kompetensi matematika dari 397 poin di tahun 2015 menjadi 379 poin di tahun 2018 (El Islami, dkk, 2018). Penurunan capaian peserta kompetisi tersebut patut dijadikan PR oleh Pemerintah untuk terus meningkatkan mutu pendidikan karena capaian masih di bawah rerata negara-negara Organitation for Economic Cooperation Development (OECD).

PISA sendiri merupakan tes ujian yang diinisiasi oleh OECD, untuk mengevaluasi sistem pendidikan di 78 negara di seluruh dunia. Soal-soal PISA yang diberikan akan menuntut siswa untuk menalar dan menyelesaikan suatu permasalahan. Seorang siswa dapat dikatakan mampu menyelesaikan masalah apabila siswa tersebut mampu mengamalkan ilmu pengetahuan yang di peroleh sebelumnya ke dalam permasalahan baru yang dihadapinya dalam kehidupan sehari-hari (Via, 2015). Kemampuan menalar dan menyelesai- 
kan masalah adalah salah satu bagian dari kemampuan literasi matematika (Yustitia \& Amin, 2020).

Literasi matematika merupakan salah satu kemampuan yang dibutuhkan untuk generasi masa depan di abad-21. Literasi matematika digambarkan sebagai kemampuan individu untuk mempertahankan kehidupan mereka di masyarakat, memiliki keterampilan membaca-menulis yang cukup untuk berkomunikasi, dan mampu menerapkan operasi matematika dasar (Juniarso, 2019). Salah satu tujuan literasi matematika adalah untuk mempromosikan pengambilan keputusan berdasarkan informasi dalam situasi kehidupan nyata dengan menggunakan keterampilan matematika untuk mengenali, menafsirkan, dan menggunakan sumber daya kontekstual secara tepat (Bansilal and Mkhwanazi, 2014; Mansur, 2018; Khairiree, 2020).

Untuk mengajarkan literasi matematika pada siswa SD, diperlukan suatu model pembelajaran yang cocok. Model pembelajaran tersebut adalah model pembelajaran Problem Based Learning (PBL). Hal itu dikarenakan kegiatan pembelajaran dengan menggunakan model PBL memiliki beberapa manfaat yaitu: (1) kecakapan siswa dalam pemecahan masalah meningkat; (2) siswa akan lebih mudah mengingat materi pembelajaran yang telah mereka dipelajari; (3) meningkatkan pemahaman siswa terhadap apa yang mereka pelajari; (4) meningkatkan kemampuannya yang relevan dengan dunia praktek; (5) membangun kemampuan siswa dalam hal kepemimpinan dan kerja sama tim; (6) memotivasi siswa untuk mengembangkan kemampuan berpikir tingkat tinggi (Yustitia, 2017; Headrick, dkk, 2020). Hal tersebut juga didukung dengan hasil penelitian Juliawan, dkk, 2017 menunjukan bahwa penerapan model pembelajaran Problem Based learning (PBL) dapat meningkatkan kemampuan pemecahan masalah. Penelitian Hidayat, dkk (2019) meyatakan bahwa penerapan model pembelajaran Problem Based Learning dapat meningkatkan kemampuan literasi matematika. Lalu hasil penelitian yang dilakukan oleh Ertikanto, dkk (2018) menunjukan terdapat pengaruh kemampuan representasi matematika yang berbeda pada hasil antara Model PBL dan DL.

Dari paparan di atas, penelitian ini ingin menjawab permasalahan: 1) apakah kemampuan literasi matematika siswa yang diajar melalui PBL lebih baik daripada rata-rata kemampuan literasi matematika yang diajar dengan model PjBL? 2) bagaimana aktivitas siswa saat diajar literasi matematika dengan model pembelajaran PBL? dan 3) bagaimana aktivitas guru saat mengajar literasi matematika dengan model pembelajaran PBL? Hasil penelitian ini diharapkan dapat bermanfaat memberikan sumbangan pemikiran yang baik dalam hal meningkatkan kualitas kegiatan literasi matematika siswa menggunakan model PBL dan dapat memberikan masukan untuk meningkatkan profesionalitas kepada para guru pada penggunaan model PBL.

\section{METODE PENELITIAN}

Penelitian ini merupakan penelitian kuantitatif. Tujuan penelitian ini adalah untuk mengetahui efektivitas 
model pembelajaran PBL terhadap kemampuan literasi matematika siswa Kelas 5 SDN Gayungan II Surabaya. Kriteria efektivitas dalam penelitian ini ditunjukan dengan rerata kemampuan literasi matematika, aktivitas siswa dan, aktivitas Guru. Rerata literasi matematika di analisis dengan statistika inferensial, sedangkan data aktivitas siswa dan Aktivitas Guru dianalisis menggunakan statistika deskriptif.

Desain penelitian yang digunakan pada penelitian ini adalah quasi experimental design tipe Post-test only. Teknik sampling yang digunakan adalah cluster random sampling. Teknik pengumpulan data yang digunakan adalah metode tes kemampuan literasi matematika, observasi aktivitas siswa dan guru, serta dokumentasi. Instrumen penelitian yang digunakan: 1) lembar validasi, 2) lembar penilaian tes kemampuan literasi matematika, 3) analisis data aktivitas siswa, 4) analisis data aktivitas guru.

\section{HASIL DAN PEMBAHASAN}

Dalam penelitian ini, data yang dikumpulkan adalah data dari hasil observasi aktivitas belajar siswa, aktivitas guru, dan hasil tes kemampuan literasi matematika

\section{Kemampuan Literasi Matematika}

Data Awal

Data awal pada penelitian ini adalah data nilai Penilaian Tengah Semester (PTS) yang diperoleh dari kedua guru kelas sampel penelitian. Kedua data tersebut digunakan untuk mengetahui apakah kedua kelas tersebut layak sebagai sampel penelitian atau tidak melalui uji prasyarat. Adapun deskriptif data nilai PTS kelas kontrol dan kelas eksperimen dapat dilihat pada Tabel 1.

Tabel 1 . Deskriptif Data Awal

\begin{tabular}{ccccccc}
\hline & \multirow{2}{*}{ N } & Mean & $\begin{array}{c}\text { Std. } \\
\text { Deviation }\end{array}$ & $\begin{array}{c}\text { Std. } \\
\text { Error }\end{array}$ & Min. Max. \\
\hline 5-A & 22 & 62.1818 & 25.66197 & 5.47115 & 20 & 100 \\
5-B & 20 & 62.7500 & 26.77759 & 5.98765 & 10 & 100 \\
Total & 42 & 62.4524 & 25.87795 & 3.99305 & 10 & 100 \\
\hline
\end{tabular}

Berdasarkan Tabel 1 dapat dilihat bahwa kelas eksperimen memiliki nilai terendah yaitu 20 dan nilai tertinggi yaitu 100 , data tersebut diperoleh dari sampel sebanyak 22 orang siswa dengan nilai rata-rata yaitu 62,18 dan simpangan baku sebesar 25,66.

Kelas kontrol memiliki nilai terendah yaitu 10 dan nilai tertinggi yaitu 100 , data tersebut diperoleh dari sampel sebanyak 20 orang siswa dengan nilai rata-rata yaitu 62,75 dan simpangan baku sebesar 26,77 .

\section{Data Akhir}

Data akhir pada penelitian ini adalah data nilai tes kemampuan literasi matematika yang diperoleh dari kedua guru kelas sampel penelitian.

\section{Deskriptif Nilai Tes Kemampuan Literasi Matematika}

Adapun deskriptif data nilai kemampuan literasi matematika kelas kontrol dan kelas eksperimen dapat dilihat pada Tabel 2 .

Tabel 2. Deskriptif Nilai Tes Kemampuan Literasi Matematika

\begin{tabular}{|c|c|c|c|c|}
\hline & N Min. & Max. & Mean & $\begin{array}{c}\text { Std. } \\
\text { Deviation }\end{array}$ \\
\hline$\overline{5-A}$ & 2125 & 100 & 78.8095 & 18.76864 \\
\hline 5-B & $22 \quad 25$ & 80 & 47.5000 & 14.12108 \\
\hline $\begin{array}{l}\text { Valid N } \\
\text { (listwise) }\end{array}$ & 21 & & & \\
\hline
\end{tabular}


Berdasarkan Tabel 2 dapat dilihat bahwa kelas eksperimen memiliki nilai terendah yaitu 25 dan nilai tertinggi yaitu 100, data tersebut diperoleh dari sampel sebanyak 21 orang siswa. Dengan nilai rata-rata yaitu 78,8095 dan simpangan baku sebesar 18,76864. Kelas kontrol memiliki nilai terendah yaitu 25 dan nilai tertinggi yaitu 80, data tersebut diperoleh dari sampel sebanyak 22 orang siswa dengan nilai rata-rata yaitu 47,5000 dan simpangan baku sebesar 14,12108.

\section{Uji Hipotesis}

Berdasarkan Tabel 3, diperoleh nilai $F_{\text {hitung }}$ yang mengasumsikan bahwa kedua varian sama adalah 0,921 dengan $\mathrm{t}=6.200$ dengan derajat kebebasan $(\mathrm{df})=\mathrm{n} 1+\mathrm{n} 2-2=21+22-$ $2=41$. Dan $\alpha=0,05$ memperoleh $t_{\text {tabel }}$ sebesar 1,68 . Maka diperoleh Sig. (2tailed) 0,000. Karena Sig. (2-tailed) $0,000<0,05$ dengan demikian $H_{O}$ ditolak, artinya rerata nilai pada kelas eksperimen lebik baik daripada kelas kontrol.

Tabel 3. Uji Hipotesis Data Akhir

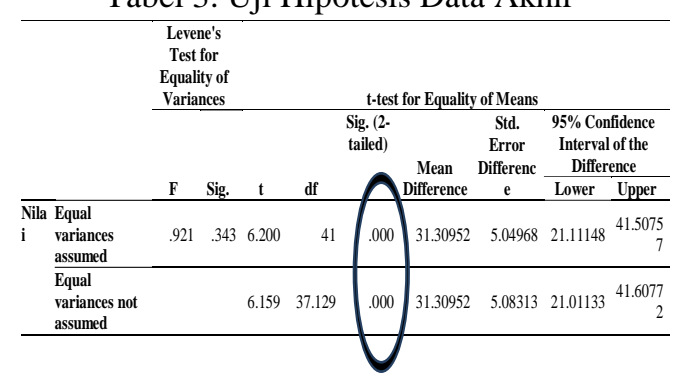

Analisis Data Instrumen Penilaian Aktivitas Siswa

Analisis data aktivitas siswa menggunakan rating scale. Analisis data observasi aktivitas siswa adalah cara peneliti untuk menghitung tingkat aktivitas siswa selama proses kegiatan belajar mengajar. Cara penentuan kategori dapat dilihat pada Tabel 4.

Tabel 4. Kriteria Penilaian Aktivitas Siswa

\begin{tabular}{cc}
\hline Rentang Nilai & Kategori \\
\hline $81-100 \%$ & Sangat Aktif \\
$61-80 \%$ & Aktif \\
$41-60 \%$ & Cukup Aktif \\
$21-40 \%$ & Kurang Aktif \\
$0-20 \%$ & Pasif \\
\hline
\end{tabular}

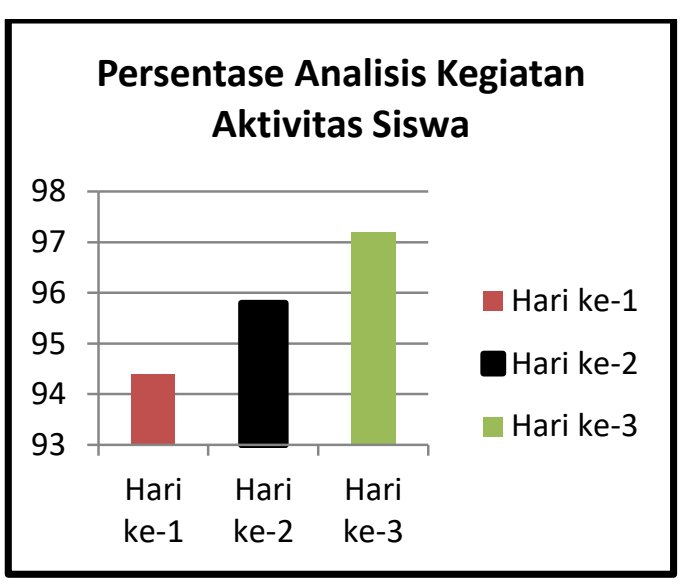

Gambar 1. Data Hasil Analisis Observasi Aktivitas siswa

Gambar 1 memperlihatkan data yang diperoleh observer dari pengamatan selama 3 hari. Dari Gambar 1 dapat disimpulkan bahwa nilai akhir pada penilaian aktivitas siswa memiliki peningkatan pada tiap harinya. Pada hari pertama mendapat kriteria sangat baik karena mendapat nilai $94,4 \%$; pada hari kedua mendapat kriteria sangat baik karena mendapat nilai 95,8\%; dan pada hari ketiga mendapat kriteria sangat baik karena mendapat nilai $97,2 \%$, artinya model PBL efektif digunakan terhadap kemampuan literasi matematika siswa Kelas 5.

\section{Analisis Data Instrumen Penilaian Aktivitas Guru}

Data observasi aktivitas guru dianalisis menggunakan statistik deskriptif 
dengan rerata skor. Penskoran pada lembar penilaian keterlakanaan pembelajaran selama kegiatan belajar berlangsung menggunakan rating scale. Cara penentuan pada penelitian ini dapat dilihat pada Tabel 5 .

Tabel 5. Kriteria Penilaian Aktivitas Siswa

\begin{tabular}{cc}
\hline Rentang Nilai & Kategori \\
\hline $81-100 \%$ & Sangat Aktif \\
$61-80 \%$ & Aktif \\
$41-60 \%$ & Cukup Aktif \\
$21-40 \%$ & Kurang Aktif \\
$0-20 \%$ & Pasif \\
\hline
\end{tabular}

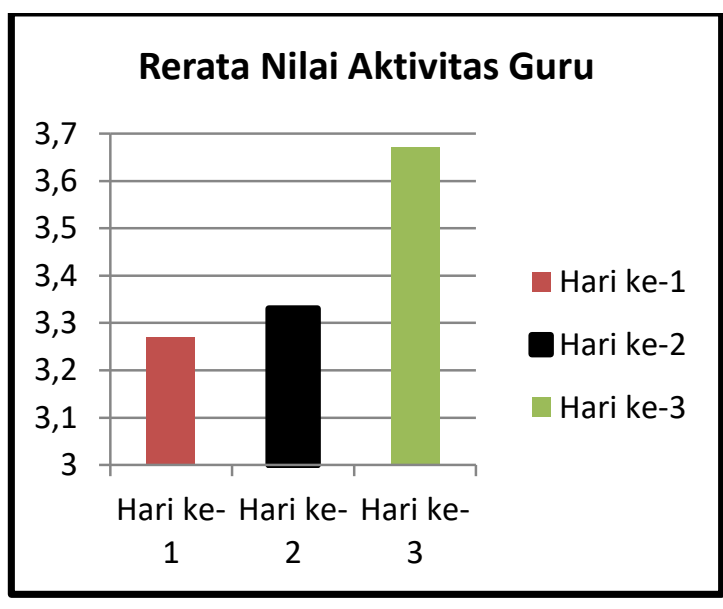

Gambar 2. Data Hasil Observasi Aktivitas Guru.

Gambar 2 adalah ringkasan data yang diperoleh observer melalui pengamatan selama 3 hari. Dari Gambar 2 dapat disimpulkan bahwa nilai akhir pada penilaian aktivitas guru memiliki peningkatan pada tiap harinya. Pada hari pertamamendapat kriteria baik karena $2,50<3,27<3,50$; pada hari kedua mendapat kriteria baik karena 2,50 < $3,33<3,50$; dan pada hari ketiga mendapat kriteria sangat baik karena 3,50 3,66 < 4,00, artinya model PBL efektif digunakan terhadap kemampuan literasi matematika siswa Kelas 5 karena mendapat hasil aktivitas guru dengan kategori baik.

\section{PEMBAHASAN}

\section{Kemampuan Literasi Matematika}

Pada hasil tes tersebut menunjukan bahwa ada perbedaan kemampuan literasi matematika siswa kelas eksperimen dan kelas kontrol. Kelas ekperimen dengan model PBL mendapatkan nilai tes yang lebih baik daripada kelas kontrol yang tidak diajar dengan model PBL. Serta indikator pada kemampuan literasi matematika pada kelas ekperimen sangat baik dan tercapai semua. Indikator kemampuan literasi matematika tersebut antara lain: (1) mengkomunikasikan secara tertulis maupun lisan; (2) menafsirkan masalah pada dunia nyata; dan (3) menerjemahkan objek matematika menjadi tabel, grafik, gambar persamaan rumus, atau benda kongkrit pada literasi matematika (Sari, 2015).

Pada kelas eksperimen semua indikator tersebut terlihat dari awal pertemuan. Namun, terdapat beberapa siswa yang kebingungan untuk menjawab soal Nomor 1, yaitu mengenai mengubah satuan waktu. Hal ini dikarenakan siswa tersebut tidak mencermati kalimat perintah yang sudah tersedia dan tidak mendengarkan penjelasan guru saat menyampaikan cara pengerjaan. Meskipun begitu siswa mampu menjawab semua soal tes dengan tepat.

Untuk soal Nomor 2-4 adalah jenis soal cerita. Siswa diharuskan menjawab soal tersebut dengan cara D3J (Diketahui, Ditanya, Dijawab, dan Jadi) untuk mendapat nilai yang sempurna. Peneliti mendapati lembar jawaban dari beberapa siswa yang tidak sesuai dengan cara pengerjaannya. Beberapa ada yang menjawab langsung, beberapa ada yang 
lupa diberi "jadi" dan beberapa ada yang lupa mencantumkan satuan diakhir jawaban.

Untuk soal Nomor 5 adalah jenis soal yang membuat siswa menalar untuk memilh solusi yang tepat untuk memecahkan permasalahan dunia nyata. Di soal Nomor 5 ini semua siswa mampu menjawab dengan tepat, dikarenakan siswa sudah paham akan satuan kecepatan. Sesuai dengan teori dari Sanjaya (Kim, dkk, 2018), model ini memberikan kesempatan pada siswa untuk mengaplikasikan pengetahuan yang mereka pilih dalam dunia nyata.

Selanjutnya untuk kelas kontrol, sangat disayangkan karena rata-rata di kelas ini masih belum paham mengenai perkalian. Jadi hal tersebut menghambat mereka untuk mendapatkan nilai yang sempurna. Siswa dikelas kontrol ini, sangat tidak suka jika menjumpai soal cerita. Mereka enggan untuk membaca soal. Beberapa siswa juga sulit menangkap apa isi penjelasan guru dikarenakan daya konsentrasi mereka kurang.

Penjelasan di atas sesuai dengan: (1) penelitian Yustianingsih (2017) yang menunjukan bahwa penerapan model PBL dapat meningkatkan kemampuan pemecahan masalah pada mata pelajaran matematika; (2) penelitian Sriwahyuni (2019) yang didapatkan bahwa penerapan model pembelajaran Problem Based Learning dapat meningkatkan kemampuan literasi matematika; dan (3) penelitian Ertikanto, dkk (2018), yang menyatakan bahwa there is difference of influence of student'smathematical representation skill to result of learning between problem based model with discovery (terdapat pengaruh kemampu- an representasi matematika yang berbeda pada hasil antara Model PBL dan DL.

Berdasarkan penjelasan di atas, dapat disimpulkan bahwa kelas ekperimen dan kelas kontrol memiliki perbedaan secara signifikan rata-rata kemampuan literasi matematika.

\section{Aktivitas Siswa}

Pada hari pertama, tanggal 24 September 2019, analisis observasi tersebut mendapatkan kategori penilaian sangat aktif. Pada pertemuan pertama siswa sangat antusias saat pembelajaran menggunakan media power point disertai dengan gambar tiket kereta api dan tiket pesawat. Hal tersebut juga terlihat pada siswa saat peneliti menanyakan satuan waktu, jarak dan kecepatan. Siswa mampu menuliskan satuan kecepatan, jarak, dan waktu di papan tulis dengan percaya diri.

Pada hari kedua, 8 Oktober 2019. Analisis observasi tersebut mendapatkan kategori penilaian sangat aktif. Hal yang menarik di hari kedua adalah peneliti membiasakan siswa untuk menjawab soal cerita dengan menggunakan cara D3J (Diketahui, Ditanya, Dijawab, Jadi) dan mengingatkan untuk mencantumkan satuan di akhir jawaban. Siswa paham akan cara tersebut dan mendapatkan nilai yang bagus. Namun masih saja banyak siswa yang lupa mencantumkan satuan di akhir jawaban.

Pada hari ketiga, 15 Oktober 2019. Analisis observasi tersebut mendapatkan nilai kategori penilaian sangat aktif. Hal yang menarik di hari ketiga adalah siswa sudah paham akan konsep kecepatan suatu benda. Siswa mampu mengetahui perbedaan kecepatan antara setiap 
benda/mahkluk yang ditayangkan di power point. Siswa juga mampu menyelesaikan masalah yang dihadapi jika menemui persoalan seperti soal tes kemampuan literasi Nomor 5.

Penjelasan di atas sesuai dengan hasil penelitian: (1) Al Ahadi (2020) yang menunjukan dengan literasi matematika, siswa akan mampu melakukan, memahami, dan menerapkan matematika dalam kehidupan sehari-hari, selain itu siswa diajak untuk berfikir kritis terhadap instruksi yang diberikan; dan (2) Manik (2020) yang menyimpulkan bahwa pembelajaran berbasis masalah efektif untuk meningkatkan kemampuan komunikasi matematis siswa. Hal ini dikarenakan dalam proses pembelajaran berbasis masalah fokus kegiatan belajar sepenuhnya berada pada siswa yaitu berfikir menemukan solusi dan memahami konsep matematika yang terkandung dalam masalah tersebut. Dalam situasi seperti itu kemampuan komunikasi matematis siswa tergali secara maksimal, karena siswa akan menfaatkan kemampuan kognitifnya dalam upaya mencari solusi dan konfirmasi terhadap pengetahuan yang ada dalam pikiran mereka. Penjelasan di atas juga sesuai dengan pendapat Kim, dkk (2018), salah satu kelebihan model PBL ialah model ini meningkatkan aktivitas pembelajaran siswa.

Hasil tersebut menunjukan bahwa model PBL berpengaruh terhadap aktivitas siswa. Hal tersebut dibuktikan oleh tabulasi hasil analisis tes kemampuan literasi matematika yang mendapat kategori A (Sangat Baik) yang artinya model PBL efektif digunakan terhadap aktivitas siswa.

\section{Aktivitas Guru}

Pada hari pertama, 24 september 2019. Analisis observasi tersebut mendapatkan kategori penilaian baik. Di hari pertama masih ada rasa canggung antara peneliti sebagai guru dengan siswa, namun suasana berubah saat guru menayangkan slide power point yang berisi gambar tiket kereta dan tiket pesawat. Guru bertanya kepada siswa apakah memiliki pengalaman akan kedua transportasi tersebut. Saat guru bertanya akan hal tersebut, siswa berubah menjadi antusias untuk menceritakan pengalamannya. Setelah itu guru bertanya lagi pada siswa, mengenai informasi apa yang dapat diambil dari kedua tiket tersebut. Dari kedua tiket tersebut siswa mampu mengira lama waktu perjalanan dari jam keberangkatan dan jam kedatangan. Dapat disimpulkan bahwa siswa sudah mampu untuk menyelesaikan suatu masalah dari kemampuan membaca tiket tersebut.

Pada hari kedua, 8 Oktober 2019. Analisis observasi tersebut mendapatkan kategori penilaian baik. Di hari kedua guru mengajarkan cara mengerjakan soal cerita mengenai Kecepatan, Jarak, dan Waktu menggunakan cara D3J. Awalnya mereka menolak untuk menggunakan cara tersebut karena terlalu lama dan ribet. Namun setelah guru menjelasan alasan bahwa cara tersebut sengat baik untuk melatih kemampuan siswa dalam hal menganalisis dan memecahkan suatu masalah, siswa mau mengerjakan soal cerita dengan cara pengerjaan tersebut.

Pada hari ketiga, 15 Oktober 2019. Analisis observasi tersebut mendapatkan kategori penilaian sangat baik. Pada guru 
mencoba untuk mengetes pengetahuan siswa tentang kecepatan suatu benda/ makhluk. Ternyata siswa sudah paham akan konsep tersebut dan mengerti perbedaan kecepatan antar benda/ makhluk. Lalu guru memberikan latihan soal agar nantinya siswa mampu menjawab soal tes kemampuan literasi matematika Nomor 5. Di latihan soal ini masih banyak siswa yang masih bingung akan pilihan mereka untuk memecahkan sebuah masalah. Penjelasan di atas sesuai dengan hasil penelitian Arta, dkk, (2020) yang menunjukan bahwa penerapan model pembelajaran Problem Based learning (PBL) dapat meningkatkan kemampuan pemecahan masalah. Dan juga sesuai dengan pendapat Sanjaya (Ahamad, dkk, 2017), yang menjelaskan bahwa model PBL memberikan kesempatan pada siswa untuk mengaplikasikan pengetahuan yang mereka pilih dalam dunia nyata dan mengembangkan minat siswa untuk secara terus menerus belajar.

Berdasarkan hasil dari analisis Aktivitas Guru selama 3 hari di atas, dapat disimpulkan bahwa model PBL berpengaruh terhadap aktivitas guru. Hal tersebut dibuktikan oleh hasil analisis observasi Aktivitas Guru yang mendapatkan kategori B (Baik).

\section{PENUTUP}

Berdasarkan data yang diperoleh dan hasil analisis data, maka dapat disimpulkan bahwa: terdapat perbedaan secara signifikan kemampuan literasi matematika di kelas eksperimen dan kelas kontrol. Kemampuan literasi matematika kelas eksperimen lebih baik daripada kelas kontrol. Aktivitas siswa dalam pembelajran literasi matematika dengan model PBL mendapatkan kategori penilaian A (Sangat Baik). Aktivitas Guru dalam pembelajaran literasi matematika dengan model PBL mendapat kategori penialian B (Baik).

\section{DAFTAR PUSTAKA}

Ahamad, S. N. S. H., Li, H. C., Shahrill, M., \& Prahmana, R. C. I. (2017, December). Implementation of problem-based learning in geometry lessons. In Journal of Physics: Conference Series (Vol. 943, No. 1, p. 012008). IOP Publishing.

Al Ahadi, F. A. I. Z. (2020). Literasi Matematika Ditinjau Dari Metakognisi Siswa Pada Pembelajaran Pjbl Berpendekatan Rme Berbantuan Edmodo (Doctoral dissertation, Universitas Negeri Semarang).

Arta, I. M., Japa, I. G. N., \& Sudarma, I. K. (2020). Problem Based Learning berbantuan Icebreaker berpengaruh terhadap kemampuan pemecahan masalah matematika. MIMBAR PGSD Undiksha, 8(2), 264-273.

El Islami, R. A. Z., Nuangchalerm, P., \& Sjaifuddin, S. (2018). Science Process of Environmental Conservation: Cross National Study of Thai and Indonesian Preservice Science Teachers. Journal for the Education of Gifted Young Scientists, 6(4), 72-80.

Ertikanto, C., Rosidin, U., Distrik, I. W., Yuberti, Y., \& Rahayu, T. (2018). Comparison of Mathematical Representation Skill and Science Learning Result in Classes with Problem-Based and Discovery Learning Model. Jurnal 
Pendidikan IPA Indonesia,7(1), 106-113.

Fanny, A. M. (2019, March). Analysis Of Pedagogical Skills And Readiness Of Elementary School Teachers In Support Of The Implementation Of The 2013 Curriculum. In International Conference on Bussiness Law and Pedagogy (Vol. 1, No. 1, pp. 5963).

Ghufron, G. (2018, September). Revolusi Industri 4.0: Tantangan, Peluang, Dan Solusi Bagi Dunia Pendidikan. In Seminar Nasional dan Diskusi Panel Multidisiplin Hasil Penelitian dan Pengabdian Kepada Masyarakat 2018 (Vol. 1, No. 1).

Headrick, L., Wiezel, A., Tarr, G., Zhang, X., Cullicott, C. E., Middleton, J. A., \& Jansen, A. (2020). Engagement and affect patterns in high school mathematics classrooms that exhibit spontaneous problem posing: an exploratory framework and study. Educational Studies in Mathematics, 105(3), 435-456.

Hidayat, R., Roza, Y., \& Murni, A. (2019). Peran Penerapan Model Problem Based Learning (PBL) terhadap Kemampuan Literasi Matematis dan Kemandirian Belajar. JURING (Journal for Research in Mathematics Learning), 1(3), 213-218.

Ibda, H., \& Rahmadi, E. (2018). Penguatan literasi baru pada guru madrasah ibtidaiyah dalam menjawab tantangan era revolusi industri 4.0. JRTIE: Journal of Research and Thought of Islamic Education, 1(1), 1-21.

Juliawan, G. A., Mahadewi, L. P. P., \& Rati, N. W. (2017). Pengaruh
Model Problem Based Learning (PBL) Terhadap Kemampuan Pemecahan Masalah Matematika Siswa Kelas III. MIMBAR PGSD Undiksha, 5(2).

Juniarso, T. (2019). Literasi Matematika Mahasiswa Dengan Gaya Belajar Visual. Malih Peddas (Majalah Ilmiah Pendidikan Dasar), 9(2), 100-109.

Kemendikbud, R. I. (2016). Desain induk gerakan literasi sekolah. Direktorat Jenderal Pendidikan Dasar dan Menengah Kementerian Pendidikan dan Kebudayaan.

Khairiree, K. (2020). Financial Literacy, Mathematics Literacy And Attitude Towards The Use Of Fintech Smartphone Apps: A Case Study Of International College, Suan Sunandha Rajabhat University. The EUrASEANs: journal on global socio-economic dynamics, (4 (23)), 29-38.

Kim, N. J., Belland, B. R., \& Walker, A. E. (2018). Effectiveness of computer-based scaffolding in the context of problem-based learning for STEM education: Bayesian metaanalysis.

Manik, M., Saragih, S., \& Zulkarnain, Z. (2020). Kemampuan Komunikasi Matematis Peserta Didik Melalui Pembelajaran Berbasis Masalah (PBM): Studi Quasi Eksperimen di SMA Negeri 1 Pangkalan Kerinci. JURING (Journal for Research in Mathematics Learning), 3(1), 101-110.

Mkhwanazi, T. W., \& Bansilal, S. (2014). Mathematical literacy teachers' engagement with contextualised income tax calculations. pythagoras, 35(2), 110. 
Sari, R. H. N. (2015, November). Literasi Matematika: Apa, Mengapa, dan Bagaimana. In Seminar Nasional matematika dan pendidikan matematika UNY (Vol. 8).

Sriwahyuni, A. (2019). Penerapan Model Pembelajaran Problem Based Learning untuk Meningkatkan Kemampuan Literasi Matematis Siswa SMP. Jurnal Didactical Mathematics, 1(2), 301051.

Via, Y. (2015). Peningkatan Kemampuan Pemecahan Masalah Melalui Pengembangan Lembar Kegiatan Siswa (LKS) dengan Pendekatan Saintifik. Wahana, 64(1), 49-57.

Yustianingsih, R., Syarifuddin, H., \& Yerizon, Y. (2017). Pengembangan Perangkat Pembelajaran Matematika Berbasis Problem Based Learning (PBL) untuk Meningkatkan Kemampuan Pemecahan Masalah Peserta Didik Kelas VIII. JNPM (Jurnal Nasional Pendidikan Matematika), 1(2), 258-274.

Yustitia, V., \& Amin, S. M. (2020, August). Mathematical literacy in pre-service elementary school teacher: A case study. In Journal of Physics: Conference Series (Vol. 1613, No. 1, p. 012054). IOP Publishing.

Yustitia, V. (2017). Kemampuan Analisis Mahasiswa PGSD Terhadap Tujuan Pembelajaran Dimensi Kognitif Pada Mata Kuliah Perencanaan Pembelajaran SD. Scholaria, 7(1), 83-93. 